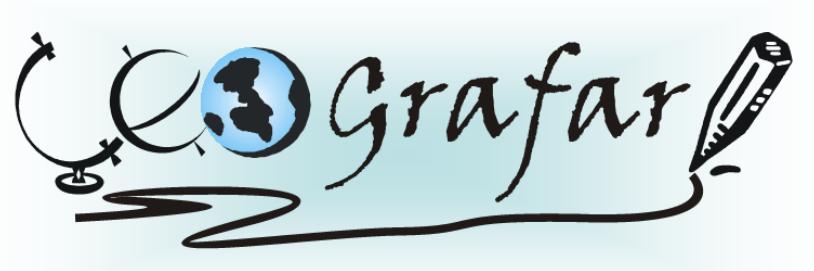

Revista Eletrônica do Programa de Pós-Graduação em Geografia - UFPR

\title{
A OCUPAÇÃO DAS ÁREAS DE PRESERVAÇÃO PERMANENTE DOS CURSOS D'ÁGUA DA BACIA HIDROGRÁFICA DO RIO BARIGUI
}

\section{LAND USE IN THE PERMANENT PRESERVATION AREAS OF THE WATER COURSES IN THE BARIGUI RIVER BASIN}

\section{(Recebido em 28.08.2014; Aceito em: 25.09.2015)}

\author{
Ana Marise Auer \\ Prof. Dra. curso de Engenharia Ambiental e Sanitária \\ Faculdade Bagozzi \\ Curitiba, PR, Brasil \\ e-mail: ana.auer@faculdadebagozzi.edu.br
}

Franklin Galvão

Prof. Dr. do Departamento de Conservação da Natureza

Universidade Federal do Paraná

Curitiba, PR, Brasil

e-mail:fgalvao@ufpr.br

Carlos Veloso Roderjan

Prof. Dr. do Departamento de Conservação da Natureza

Universidade Federal do Paraná

Curitiba, $P R$, Brasil

e-mail: roderjan@ufpr.br

\begin{abstract}
RESUMO
O estudo realizado delimitou as Áreas de Preservação Permanente dos cursos d'água da bacia do rio Barigui e das áreas de nascentes, a fim de identificar os usos nelas estabelecidos. Para tanto foram usadas ferramentas de análise especial sobre a base cartográfica oficial do Estado do Paraná e imagens do satélite QuickBird do ano de 2006. A delimitação das APP compreendeu a geração de um buffer em ambiente SIG ao longo dos cursos d'água e feições hídricas associadas, com distâncias de $50 \mathrm{~m}$ ao longo do rio Barigui, nascentes e espelhos d'água, $30 \mathrm{~m}$ ao longo dos afluentes e delimitação de áreas de várzea. A análise evidenciou que $62 \%$ das APP estão ocupadas por urbanizações, $1,09 \%$ por atividades de extração mineral, $2,38 \%$ por agricultura, e $6,83 \%$ por floresta ripária pouco alterada. A
\end{abstract}


vegetação remanescente encontra-se em estágio de sucessão intermediária $(20,81 \%)$ e em estágio inicial (18,55\%). O trabalho conclui que apesar da vigência de ampla legislação determinando a intangibilidade das APP os órgãos responsáveis pelo planejamento e fiscalização dessas áreas não tem se mostrado em condições para implantá-las, o que se associa à falta de vontade política para impor medidas de reordenamento territorial que no presente teriam impacto negativo nas urnas porém, apesar dos benefícios para as futuras gerações.

Palavras-chave: Área de Preservação Permanente - APP, rio Barigui, ocupação de APP.

\section{ABSTRACT}

This study delimited the Permanent Preservation Areas (PPA) of streams and springs in order to identify their land use patterns. To do so, spacial analysis tools were applied, using official cartographic maps of the State of Paraná and 2006 QuickBird satellite images. The PPA delimitation was performed in a GIS environment producing buffers along streams and other associated watershed features. Buffers for the Barigui river, springs and lakes were produced with $50 \mathrm{~m}$, and buffers for tributaries and wetlands were produced with $30 \mathrm{~m}$. The analysis demonstrated that $62 \%$ of the PPA were occupied by urbanization, $1,09 \%$ by mineral extraction, $2,38 \%$ by agriculture, and $6,83 \%$ by slightly disturbed riparian forest. The remnant vegetation is in a intermediate succession stage $(20,81 \%)$ or in na initial stage of succession (18,55\%). The study concludes that, in spite of the extensive legislation determining the untouchability of the PPA, the environmental organs in charge of planning and enforcing those areas do not show the capabilities to implement it. More on when this is associated with the lack of political will to impose land use reordering with negative electoral impact at the present moment, even though they bring benefits for future generations.

Keywords: Permanent Protect Areas - PPA, Barigui river, watershed land use.

\section{INTRODUÇÃO}

É sabido que a destruição histórica dos ecossistemas florestais originais teve como justificativa a necessidade da disponibilização do espaço geográfico inicialmente para o estabelecimento de moradias e posteriormente para a ampliação de áreas compreendidas como urbanas, demandando ainda outros espaços para o estabelecimento e expansão de áreas agrícolas necessárias à produção de alimentos para uma população em exponencial crescimento.

Auer (2010) descreve que o critério disponibilidade de água, ou seja, a presença de um curso d'água com qualidade e quantidade satisfatórias para atender as necessidades humanas, historicamente, foi o fator determinante na eleição do 
espaço geográfico para o estabelecimento inicialmente de povoados e vilas. Logo, a degradação dos cursos d'água foi e continua sendo uma consequência da ocupação das margens dos rios eleitos para aqueles fins.

Os impactos socioambientais decorrentes do processo de colonização e desflorestamento no Sul do Brasil, na primeira metade do século XX (CARVALHO, 2012), foram também denunciados por Reinhard Maack já em 1961, manifestando: "são passados os tempos em que os córregos e rios, com suas águas límpidas, enfeitavam as paisagens; águas sujas, amarelas e vermelhas são agora conduzidas rio abaixo."

No contexto de desmatamento de florestas nativas, conforme descreve Auer (2010), particularmente daquelas situadas em ambientes ripários de rios presentes em espaços urbanos, muito embora haja de longa data uma legislação que promova a sua proteção integral, o Código Florestal Brasileiro (BRASIL, 2012), que classificou esse espaço, desde 1965, como Área de Preservação Permanente, ainda são paulatinamente degradadas devido à falta ou dissociação do planejamento urbano com o planejamento territorial embasado em critérios de sustentabilidade mutualística, acrescido da falta de percepção ou priorização política para com as questões ambientais desses locais.

Ainda, de acordo com AUER (2010), uma das consequências da eliminação da vegetação nativa ao longo dos cursos d'água de áreas urbanas é que tais espaços se tornaram uma alternativa de assentamento para aqueles habitantes social e economicamente desfavorecidos que buscam um lugar para morar, e que, através de um círculo vicioso, extinguem a vegetação no espaço disponível, ou para aqueles que, se valendo da aparente falta de controle governamental, encontram oportunidades para a especulação imobiliária com loteamentos irregulares criando um círculo vicioso que extingue a vegetação e degrada os recursos hídricos.

No panorama de ocupação urbana desordenada, a água, ainda que seja um recurso natural indispensável à vida, fica relegada ao papel de receptor e transportador de resíduos despejados nos cursos d' água, muitas vezes in natura, pela insuficiência de infra estrutura. Bollmann et al. (2006) afirmam que parte dessa poluição gerada em áreas urbanas tem origem também no escoamento superficial das águas de chuva sobre áreas impermeáveis e em redes de drenagem, pois 
carregam materiais orgânicos e inorgânicos em suspensão ou solúveis aos mananciais, aumentando significativamente sua carga de poluentes.

O processo de ocupação do espaço geográfico onde se formou a cidade de Curitiba, capital do estado do Paraná, não diferentemente ao de outros centros urbanos, seguiu um caráter espontâneo e anárquico, priorizando, também, as áreas de proximidade aos cursos d'água como espaços aptos ao assentamento da população imigrante. Este padrão de ocupação irracional tem-se mantido ao longo da história gerando na atualidade conflitos de ordem ecológica, social e legal, de difícil solução quando considerado o impacto sócio econômico e especialmente o impacto político das alternativas técnicas disponíveis (AUER, 2010).

A bacia do rio Barigui, sub-bacia do rio Iguaçu (IAP, 2009), está inserida na Região Metropolitana de Curitiba, apresentando suas nascentes no município de Almirante Tamandaré e sua foz no rio Iguaçu, no município de Araucária. O principal curso d'água da bacia, o rio Barigui, conforme descreve AUER (2010), assume uma posição socioambiental significativa, atravessando populosos bairros da cidade de Curitiba, ao mesmo tempo em que em seu percurso compreende áreas públicas como o Parque Tanguá e o Parque Barigui, este o segundo maior parque urbano da Capital, e por isso um ponto de atração diária de milhares de visitantes locais e outros de distintas origens que buscam naquele espaço alternativas de lazer e bem estar.

Ainda, conforme AUER (2010), a bacia do rio Barigui apresenta um conjunto variado e historicamente extenso de excessos na ocupação predatória do espaço, especialmente sobre as áreas de preservação permanente, demandando modificações estruturais profundas, tanto na distribuição espacial da ocupação como no disciplinamento das atividades antrópicas, para atingir uma situação técnica e legalmente aceitável e compatível com critérios objetivos de sustentabilidade.

No contexto de atual estado de degradação da bacia hidrográfica do rio Barigui, ocupada por densa urbanização que desconsiderou parâmetros efetivos para o conhecimento sistêmico e a regulação do uso sustentável dos recursos naturais, o presente estudo teve como objetivo delimitar as áreas de preservação permanente em ambiente ripário dos cursos d’água dessa bacia hidrográfica, identificando e avaliando a ocupação ali estabelecida, apesar desta estar vedada pela legislação atualmente vigente. 


\section{Localização e caracterização da área de estudo}

O área de estudo é a bacia hidrográfica do rio Barigui (Figura 1). Inserida no primeiro planalto paranaense (MAACK, 1981), a área tem coordenadas de latitude 25013'24" e 25038'23" sul e longitude 49015'00" e 49022'29" oeste, e compreende 279 km2. Sua extensão é de 66 km.

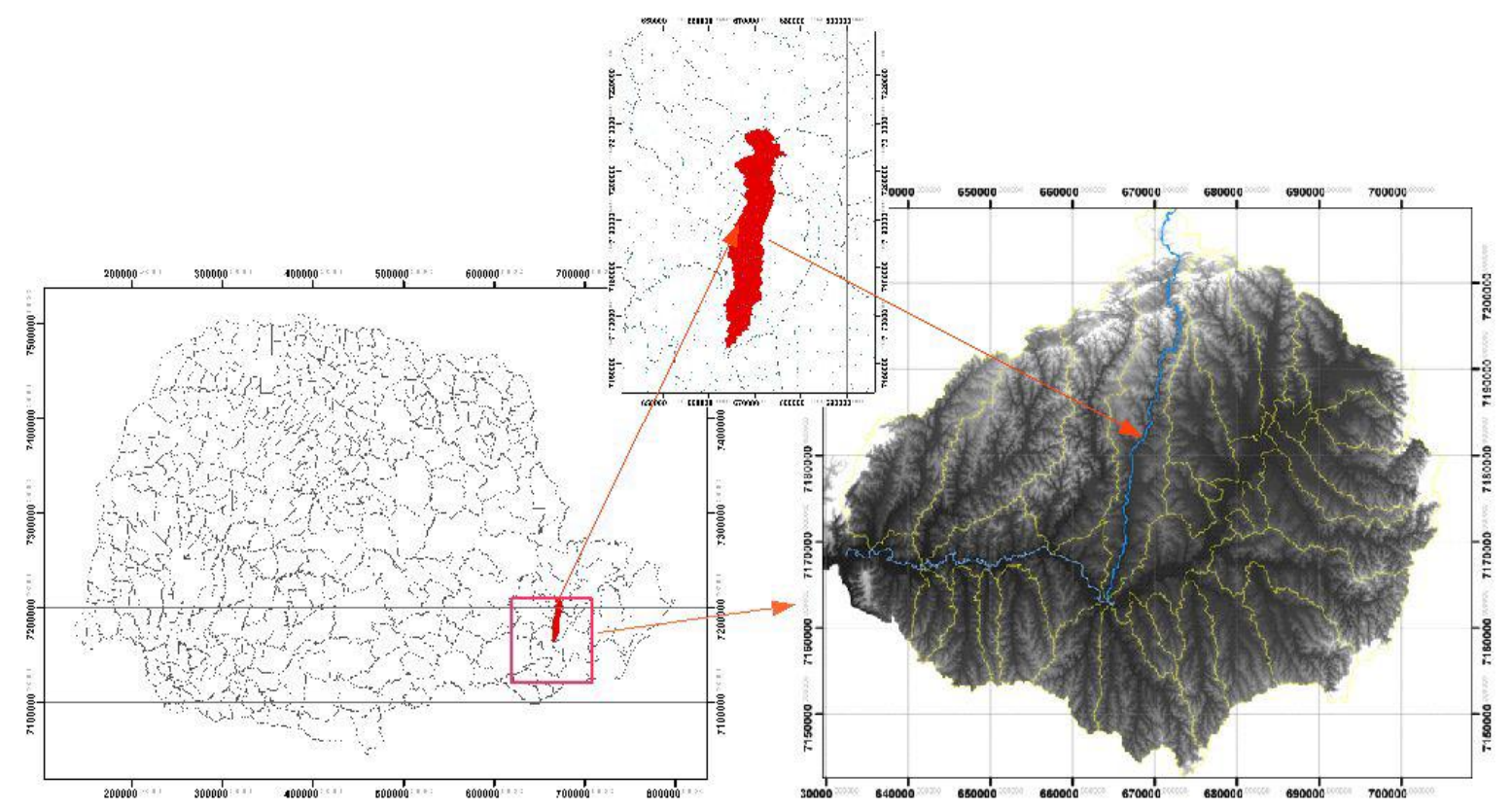

Figura 1: LOCALIZAÇÃO DA BACIA DO BARIGUI NO ESTADO DO PARANÁ. Fonte: Auer (2010).

As nascentes de seu principal curso d'água, o rio Barigui, situam-se nos municípios de Almirante Tamandaré e Colombo e sua foz é no rio Iguaçu, no município de Araucária (FILL et al., 2005). É na porção central da Bacia onde localiza-se o município de Curitiba, capital do estado do Paraná (AUER, 2010).

A área do presente estudo, conforme a classificação climática de Koppen, está inserida em uma região com o tipo $\mathrm{Cfb}$, definido clima temperado propriamente dito, apresentando temperatura média no mês mais frio abaixo de $18^{\circ} \mathrm{C}$ (mesotérmico), com verões frescos, e temperatura média no mês mais quente abaixo de $22^{\circ} \mathrm{C}$ e sem estação seca definida (NETO, 2010). Quanto aos tipos de solos mapeados na Bacia por Auer (2010), são presentes os Cambissolos háplicos distróficos típicos, os Argissolos vermelhos-amarelos, os Latossolos vermelhos e Gleissolos.

O enquadramento fitogeográfico da bacia do rio Barigui é da Floresta Ombrófila Mista, conforme descreveu originalmente Veloso \& Góes-Filho (1982), tendo sido adaptado por Veloso et al. (1991), para a classificação da vegetação brasileira 
publicada por IBGE (1992). Nessa fitofisionomia duas sub-formações são características na bacia do rio Barigui: a Floresta Ombrófila Mista Montana e a Floresta Ombrófila Mista Aluvial (AUER, 2010).

A Floresta Ombrófila Mista Montana consiste numa floresta densa, sombria e exuberante, composta por espécies praticamente sem adaptação à seca, sendo a Araucaria angustifolia (Bertol.) Kuntze - Araucariaceae, popularmente conhecida como pinheiro-do-paraná, com suas folhas esclerófilas, uma das raras exceções. Outras espécies presentes nessa tipologia florestal perdem as folhas no inverno, 0 que faz com que nessa estação do ano a luminosidade no interior da floresta seja maior, embora a porcentagem de caducifólias não ultrapasse $20 \%$ do total (BOLÓS, CERVI \& HATSBACH, 1991). Auer (1995) aponta que a área remanescente desse tipo de vegetação no Paraná compunha $8 \%$ da área original protegida através de unidades de conservação. Conforme PROBIO (2010), essa tipologia florestal em 2002 cobria 20.000 km² do estado do Paraná, ou seja, cerca de seu 10\% território. Contudo, é somente através da Lei 11.428/2006 que a Floresta Ombrófila Mista, uma formação florestal integrante do Bioma Mata Atlântica, passa a ser objeto de preservação da biodiversidade do País e, portanto, sendo proibido o corte de qualquer espécie característica desse tipo de vegetação.

A Floresta Ombrófila Mista Aluvial corresponde às florestas ripárias, também denominadas de florestas ciliares ou de galeria, que se desenvolvem às margens de rios que percorrem terrenos de geomorfia plana até suave-ondulada, não raro fazendo limite a várzeas (formações pioneiras) de extensão variável. Essa vegetação pode apresentar-se em diferentes graus de desenvolvimento, desde comunidades simplificadas condicionadas pelo grau de hidromorfia dos solos Neossolos Flúvicos e Gleissolos -, onde Sebastiania commersoniana (Baill.) L.B. Sm. \& Downs - Euphorbiaceae -, é a espécie mais característica, até associações mais complexas em que Araucaria angustifolia tem ocorrência expressiva (RODERJAN et al., 2002), sendo considerada um clímax edáfico.

Também a Estepe, conhecida popularmente por campo, é uma formação típica do primeiro planalto paranaense que, de acordo com RODERJAN et al. (2002), é uma vegetação de constituição essencialmente graminóide, estabelecida em terrenos suave ondulados, sendo originalmente entremeada por capões, ou seja, núcleos da floresta ainda com a composição original da Floresta Ombrófila Mista. 
Conforme descreve Auer (2010), o curso do rio Barigui na porção norte da sua bacia é acompanhado pela rodovia PR 002, a qual faz a ligação entre os municípios de Almirante Tamandaré e Curitiba. Ao longo dessa rodovia, nas áreas vizinhas ao rio Barigui, o número de estabelecimentos comerciais e de serviços ocupando aquele espaço, bem como o de áreas urbanizadas, é significativo, porém inexistem aí remanescentes da vegetação nativa a qual era composta por densas florestas com o predomínio de Araucaria angustifolia. Hoje essa área está ocupada por atividades socioeconômicas intensivas como a extração de calcário e a agricultura. Já, a porção sul da bacia do Rio era originalmente dominada pelos campos naturais entremeados pelos capões de floresta com o pinheiro-do-paraná. Ainda, os cursos dos rios e afluentes eram acompanhados pelas florestas de galeria, ou ripárias, formadas por um pequeno número de árvores de porte médio destacando-se pela sua abundância Sebastiana klotzchiana (Müll.Arg.) Müll.Arg. - Euphorbiaceae -, presente ainda hoje em raros remanescentes. Na parte leste dessa porção da Bacia e também na sua porção central os vastos campos edáficos ou campos de inundação ocupavam as áreas de várzea do rio e seus afluentes, assim como outros lugares baixos e sujeitos a inundações periódicas.

$\mathrm{Na}$ porção sul da bacia, no município de Araucária, está localizada a Refinaria Getúlio Vargas - REPAR da Petrobrás, uma das indústrias mais importantes da $\mathrm{RMC}$, tendo sido responsável, no ano de 2000, pelo mais grave incidente de contaminação ambiental do País, derramando mais de 4 milhões de litros de óleo cru no arroio Saldanha, afluente do Barigui, atingindo um segmento de mais de seis quilômetros da sua porção final e chegando ao rio Iguaçu (AUER, 2009).

A urbanização é hoje presente em toda a bacia hidrográfica estudada, porém é na sua porção central, no município de Curitiba, onde a densidade é maior, apresentando os impactos mais significativos da degradação de faixas ribeirinhas e áreas inundáveis característicos do crescimento urbano no País. De acordo com Auer (2010), alguns deles são:

a) Densa ocupação de margens e áreas inundáveis por construções irregulares, com degradação ou erradicação da vegetação nas APP;

b) Lançamento de esgoto in-natura diretamente nos cursos d'água, incluindo efluentes domésticos e poluentes industriais; 
c) Instituições públicas encarregadas do planejamento e ordenamento territorial urbano que demonstram, na prática, um entendimento meramente paisagístico das limitantes ecológicas das APP;

d) Uso de medidas paliativas de curto prazo, em geral associadas a obras de engenharia, que permitam contornar os problemas estruturais, estabelecendo um permanente quadro de exceção, onde os paliativos se transformam em regra, evitando-se, com isso, cumprir com as exigências legais que, nesses casos a classe política usualmente diz eufemisticamente que "a lei não pegou".

\section{MATERIAIS E MÉTODO}

O polígono da bacia do rio Barigui foi construído com base na cartografia cedida pela COMEC (2002) e SUDERHSA (2007), em escalas que variam de $1: 50.000$ a $1: 8.000$.

A hidrografia utilizada, cedida pela SUDERHSA, é datada de 2002. Como essa cartografia encontrava-se em diversos formatos e sistemas de projeções, os arquivos foram padronizados no formato Shapefile e no sistema de projeção SAD69 UTM22S.

Para a avaliação da ocupação urbana sobre as Áreas de Preservação Permanentes, foi utilizado também um layer de ocupações irregulares produzido pela SANEPAR (2002), cedido pela COMEC. Nele é apresentado o último registro oficial com dados gerados pela COMEC \& IPUC (2002), totalizando 535,60ha, distribuídos em 188 vilas.

Para a avaliação da ocupação recente das áreas de interesse da área de estudo foram utilizadas imagens de satélite QuickBird multiespectral, com banda infravermelha, com resolução radiométrica de 11 bits e resolução espacial de 2,44m, adquiridas para a porção superior e porção inferior da Bacia. Para a região central, foram utilizadas imagens QuickBird fusionadas, disponibilizadas pelo sistema Google Earth Pro, capturadas entre agosto de 2005 e julho de 2006, sendo reamostradas a uma resolução espacial de $1,00 \mathrm{~m}$. Devido ao processo de fusão e reamostragem as imagens extraídas do Google Earth Pro não apresentam informação espectral útil, contudo em função da sua resolução espacial são 
adequadas para a restituição planimétrica das feições urbanizadas e escassa vegetação remanescente, assim como para o ajuste da hidrografia.

A cartografia legada foi processada eliminando os erros topológicos e geométricos, sendo reprojetada em SAD69 UTM22S.

As imagens QuickBird (Figura 2) foram ortorretificadas utilizando dados da orbita do sensor, pontos de apoio obtidos com GPS com precisão melhor que 0,5m e - Modelo Digital de Terreno - MDT gerado com resolução de $2 \mathrm{~m}$, utilizando as curvas de nível e pontos cotados fornecidas pela COMEC, na escala 1:10.000. Da mesma forma, foram utilizados pontos de apoio e pontos de controle extraídos da cartografia legada.

Após serem ortorretificadas, as imagens multiespectrais foram submetidas a ajustes de contraste e melhora de definição de bordas, no intuito de facilitar o processo de delineamento de feições a serem restituídas planimetricamente. $\mathrm{Na}$ avaliação da ocupação antrópica nas áreas de preservação permanentes deu-se ênfase ao processo de degradação da cobertura vegetal, tanto na sua extensão, erosão da riqueza tipológica e qualidade da sua composição. Para isso, a interpretação da imagem seguiu critérios de avaliação fitoecológica e de correlação entre padrões espaciais de variabilidade da vegetação, acompanhados de confirmação e detalhamento das feições identificadas em campo.

Os dados foram processados com técnicas de sobreposição em um Sistema de Informações Geográficas - SIG dos layers vetoriais obtidos e gerados na restituição. Para isso, foi implementado um banco de dados geográficos em PostgreSQL/PostGIS, licenciado como Software Livre, de forma a poder utilizar as funcionalidades de análise espacial, de acordo com a especificação Feição Simples para SQL - SFS, do Consórcio OpenGIS - OGC, sendo homologado como padrão ISO sob o código ISO/TC 211, por ele oferecidas (RAMSEY et al., 2007). Desta forma, a análise realizada utilizou-se de scripts de Structured Query Language SQL, padrão ISO/IEC 9075, gerando layers derivados com os dados consultados utilizando o SIG GCJ, implementado com o framework OpenJUMP, Software Livre mundialmente utilizado (Figura 3). 

RIO BARIGUI

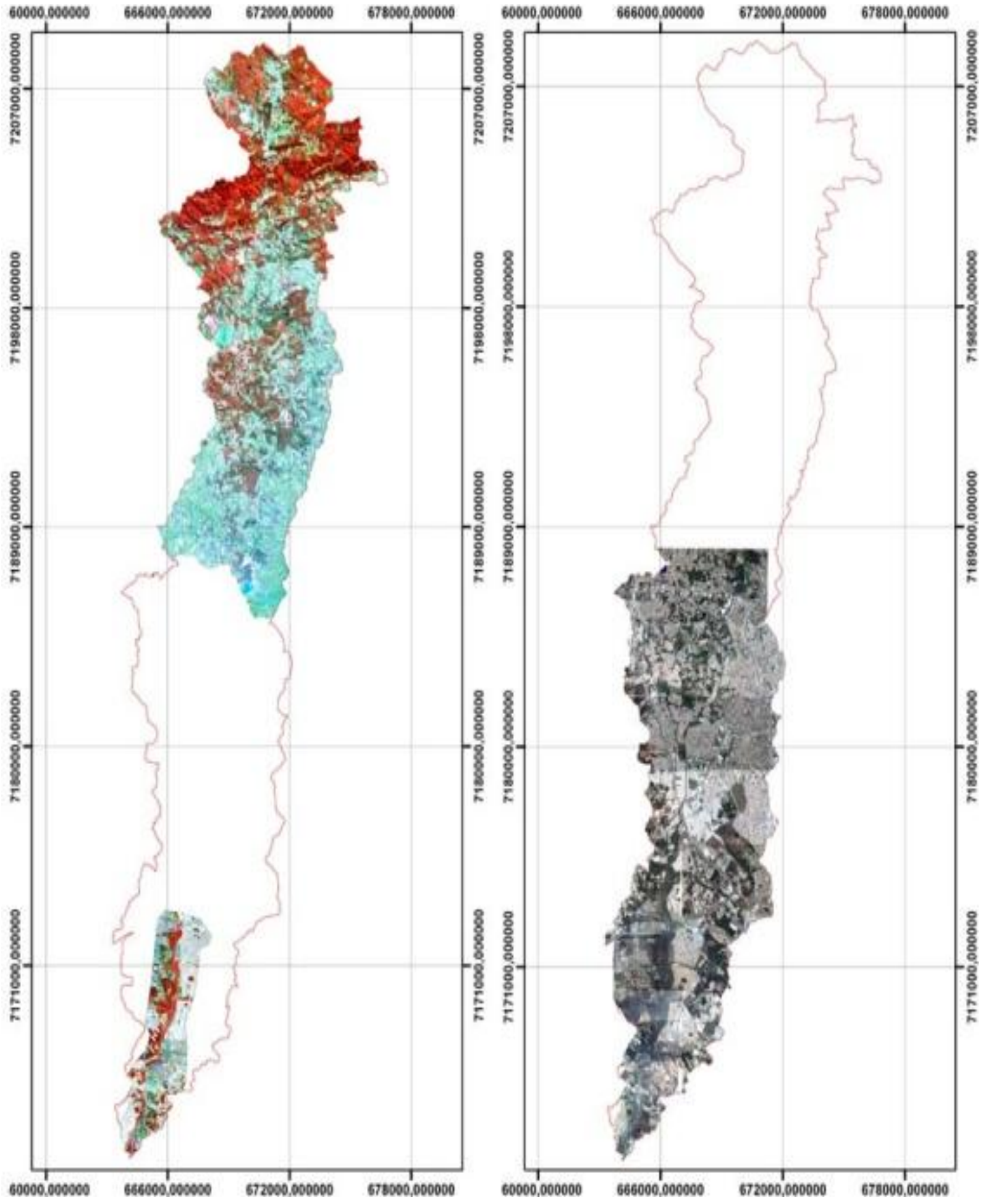

Figura 2: IMAGEM QUICKBIRD: BANDA INFRAVERMELHA (esquerda) E PAN-RGB FUSIONADA EXTRAÍDA DO GOOGLE EARTH PRO (direita). Fonte: Auer (2010). 


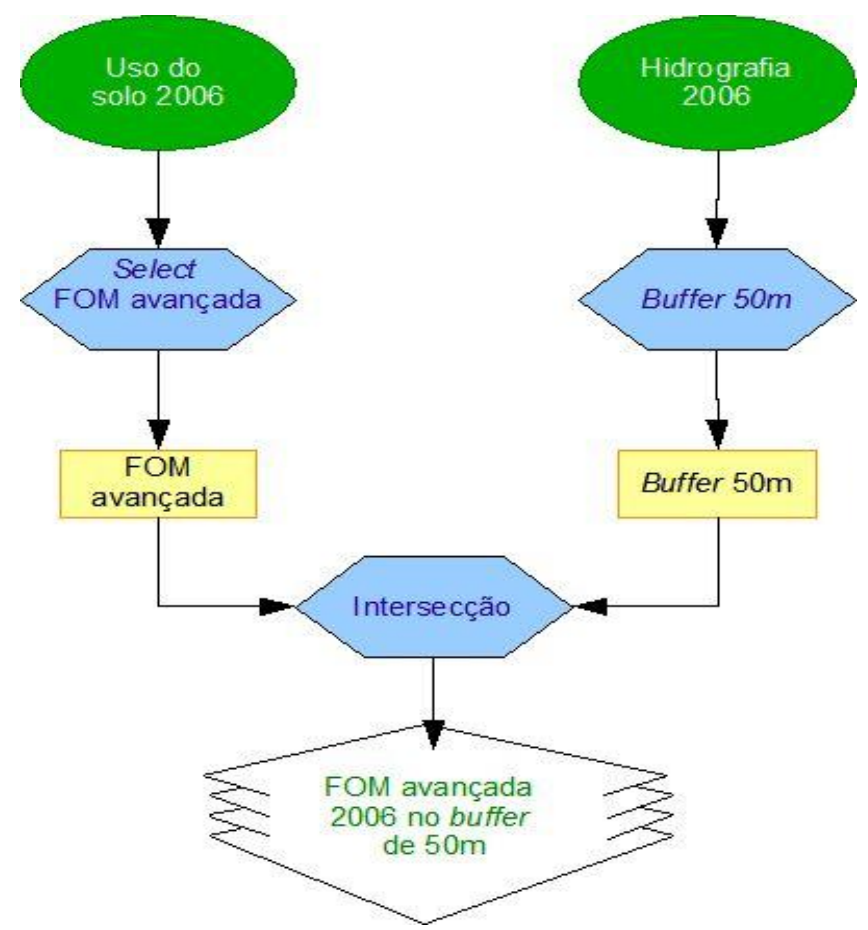

Figura 1: DIAGRAMA DE UMA CONSULTA SQL ESPACIAL NO BANCO DE DADOS GEOGRÁFICO POSTGIS. Fonte: Auer (2010).

A delimitação das áreas inundáveis foi extraída do mapeamento fornecido por SUDERHSA e produzido pela MINEROPAR (2002).

A delimitação das áreas de preservação permanente ao longo dos rios componentes da bacia do rio Barigui seguiu os critérios estabelecidos na legislação federal, no Código Florestal Brasileiro, gerando um buffer (faixa de vizinhança) em ambiente SIG ao longo dos cursos d'água e feições hídricas associadas, com as seguintes distâncias:

a) Buffer de $50 \mathrm{~m}$ ao longo do rio Barigui, nascentes e espelhos d'água;

b) Buffer de $30 \mathrm{~m}$ ao longo dos afluentes;

c) Área total das áreas inundáveis (várzeas).

Seguidamente, foi extraído um layer de uso do solo dentro do perímetro definido pelo bufer e realizado o cálculo da área ocupada por cada unidade de mapeamento.

O banco de dados espaciais foi implementado com os seguintes layers:

a) Uso do solo e vegetação.

b) Ocupação irregular.

c) Áreas de Preservação Permanente. 
O critério de análise territorial foi determinado pelo quadro legal vigente, em nível federal, estadual e municipal, que rege a ocupação do espaço da área de estudo, ou seja, considerando a aplicação da legislação específica referente à áreas de preservação permanente ao longo de recursos hídricos. Assim, as Áreas de Proteção Permanente da malha hidrográfica da bacia do rio Barigui foram classificadas da seguinte maneira:

a) Buffer de $50 \mathrm{~m}$ ao longo do rio Barigui e nascentes;

b) Buffer de $30 \mathrm{~m}$ ao longo de seus afluentes.

A análise dos dados foi realizada a partir dos resultados do processamento por sobreposição em SIG dos layers produzidos.

Os dados calculados se referem à área total, em hectares, coberta pela unidade de mapeamento de uso do solo.

\section{RESULTADOS E DISCUSSÃO}

A análise da malha hidrográfica da bacia Barigui gerada demonstrou uma estrutura dendrítica e muito sinuosa e originalmente com a presença de largas áreas de várzea, concentradas principalmente na sua porção sul.

O rio Barigui ainda hoje apresenta trechos meândricos, muito embora seu leito em sua porção central, no município de Curitiba, tenha sofrido obras de retificação e aprofundamento de sua calha, também descrito por (YAMAMOTO, 2012), com o objetivo de conter o espraiamento de suas águas nas épocas de chuva intensa.

Tendo sido realizado o mapeamento do uso do solo ao longo dos cursos hídricos da bacia do rio Barigui (Figura 4), ou seja, nas áreas de área de preservação permanente - APP, foram sistematizadas as seguintes classes de ocupação:

a) Urbana;

b) Agricultura;

c) Extração mineral;

d) Floresta Ombrófila Mista (FOM) Avançada;

e) Floresta Ombrófila Mista (FOM) Intermediária;

f) Floresta Ombrófila Mista (FOM) Inicial.

Ressalta-se que os remanescentes da Floresta Ombrófila Mista mapeados na área do estudo são secundários. De acordo com a Resolução CONAMA No. 2/1994, a 
vegetação secundária é resultante de processos naturais de sucessão, após supressão total ou parcial de vegetação primária por ações antrópicas ou causas naturais, podendo ocorrer árvores remanescentes de vegetação primária. Ainda, os estágios sucessionais de regeneração da vegetação secundária são descritos no Artigo 5․ desta mesma Resolução como: inicial, médio e avançado, os quais têm suas delimitações para o estado do Paraná, estabelecidas pelo Mapa de Vegetação do Brasil - IBGE - 1988.

Considerando as particularidades das fragilidades das diferentes feições hídricas (buffer dos rios, nascentes, áreas inundáveis, espelhos d'água), a análise foi feita separadamente para cada uma das classes acima estabelecidas.

Considerando unicamente o buffer de $50 \mathrm{~m}$ ao longo do rio Barigui, $30 \mathrm{~m}$ ao longo dos afluentes e $50 \mathrm{~m}$ ao redor das nascentes, a área total de APP das zonas ripárias é de 6417,7 ha, existindo 1527 nascentes perfazendo 1196,10 ha de APP desse tipo de feição hídrica. Do total daquela área, 53,89\% está ocupada por urbanizações (Tabela 1), sendo que 456 nascentes estão eliminadas, desaparecendo totalmente a drenagem a elas associada (Figura 5).

A vegetação da Floresta Ombrófila Mista em estágio sucessional avançado é caracterizada por remanescentes de vegetação florestal formada por um grupo pequeno de espécies do qual Sebastiania commersoniana é a espécie característica dominante, ocupando 3,29\% da área total de nascentes. Esta situação é verificada principalmente na porção sul da bacia hidrográfica estudada. Ainda, 17,56\% desse espaço da bacia do rio Barigui estão ocupados pelo mesmo tipo de vegetação, porém em estágio sucessional intermediário e 21,96\% por essa vegetação em estágio sucessional inicial, este representado por maciços florestais compostos por Mimosa scabrella Benth - Mimosaceae -, popularmente conhecidos como bracatingais, os quais são intensamente manejados com o objetivo de produção de lenha, particularmente na porção norte da bacia. 


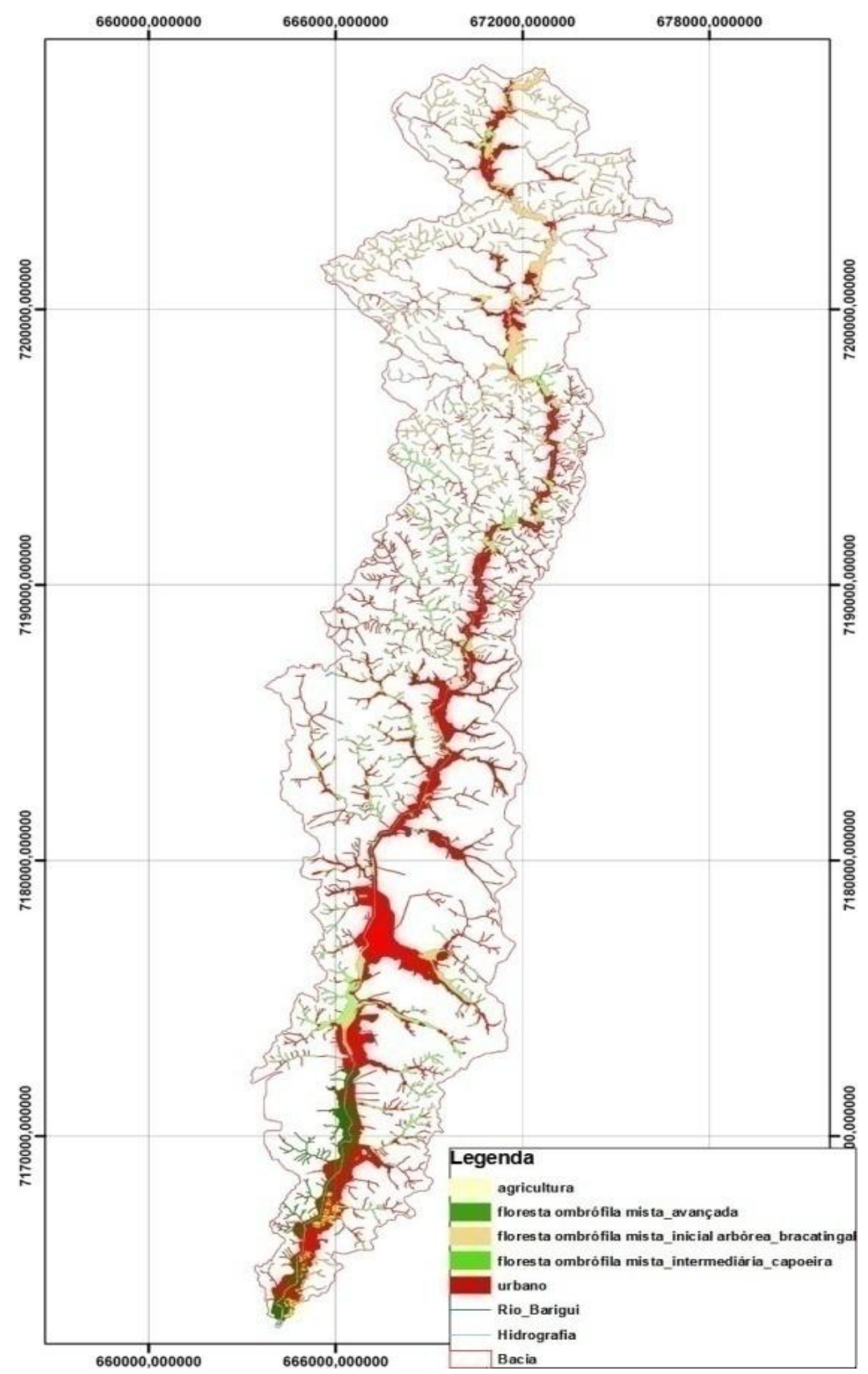

Figura 4: USO DO SOLO NAS ÁREAS DE APP DOS CURSOS D'ÁGUA DA BACIA DO RIO BARIGUI. Fonte: Organizado pelo Autor (2010). 
Tabela 1: Ocupação da APP das nascentes do rio Barigui.

\begin{tabular}{|l|l|l|l|l|l|l|}
\hline & Urbana & $\begin{array}{l}\text { Agricultur } \\
\text { a }\end{array}$ & $\begin{array}{l}\text { Extração } \\
\text { Mineral }\end{array}$ & $\begin{array}{l}\text { FOM } \\
\text { Avançada }\end{array}$ & $\begin{array}{l}\text { FOM } \\
\text { Intermediá } \\
\text { ria }\end{array}$ & $\begin{array}{l}\text { FOM } \\
\text { Inicial }\end{array}$ \\
\hline $\begin{array}{l}\text { Área Total } \\
\text { (ha) }\end{array}$ & 637 & 37,09 & 1,95 & 38,85 & 207,62 & 259,57 \\
\hline $\begin{array}{l}\text { Área } \\
\text { Média }\end{array}$ & 0,45 & 0,32 & 0,16 & 0,47 & 0,3 & 0,55 \\
\hline $\begin{array}{l}\mathrm{N}^{0} \text { de } \\
\text { Polígonos }\end{array}$ & 1421 & 117 & 12 & 83 & 688 & 469 \\
\hline$\%$ & $53,89 \%$ & $3,14 \%$ & $0,16 \%$ & $3,29 \%$ & $17,56 \%$ & $21,96 \%$ \\
\hline
\end{tabular}
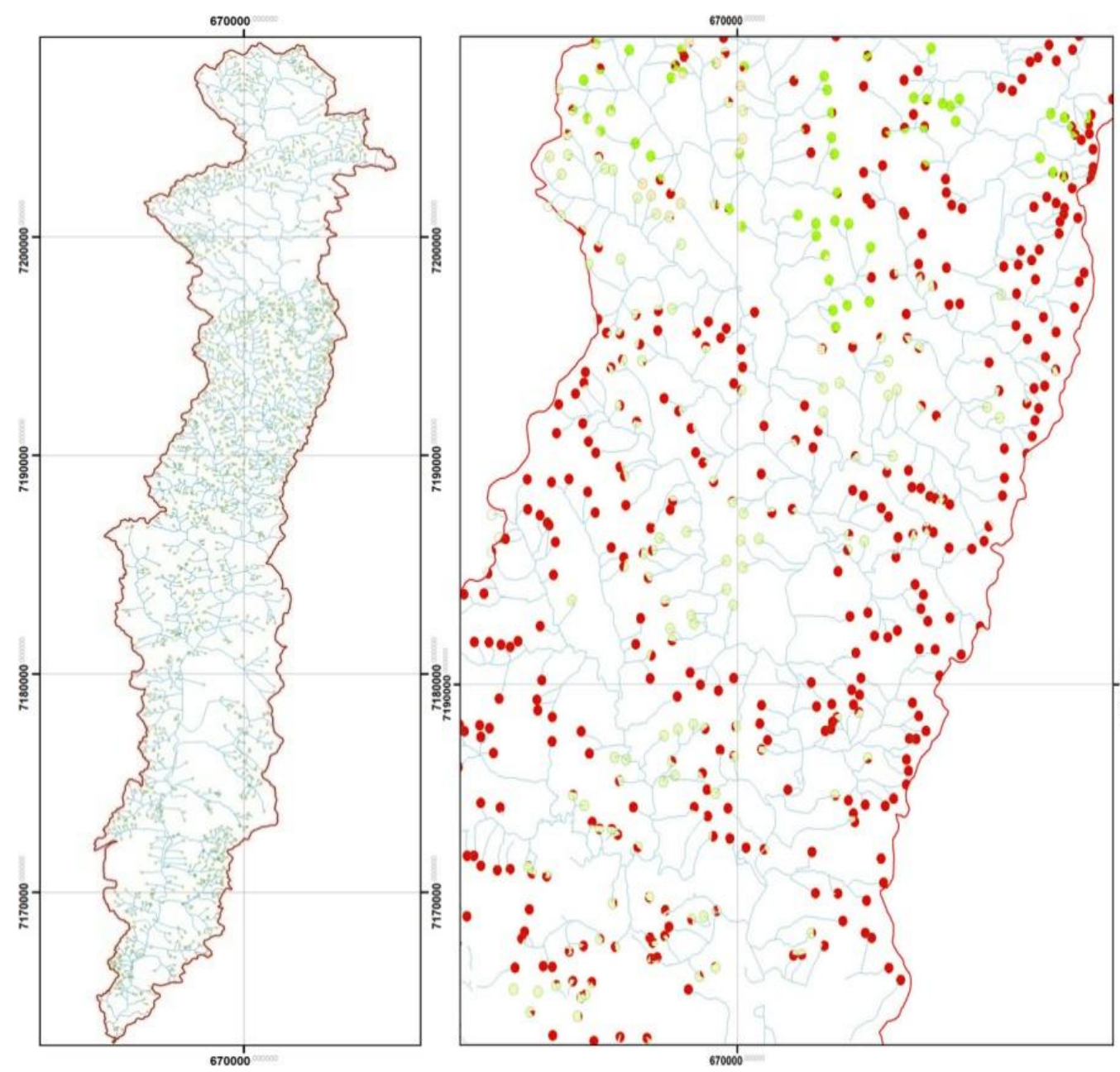

Figura 5: NASCENTES EXISTENTES NA BACIA DO RIO BARIGUI (ESQUERDA); DETALHE DA PORÇÃO CENTRAL DA BACIA, ENFATIZANDO A DENSIDADE DE NASCENTES ELIMINADAS, EM VERMELHO (DIREITA). Fonte: Organizado pelo Autor (2010). 
Um indicador do alto nível de degradação das nascentes é a presença de atividades de extrativismo mineral, tanto de areia e argila, como de calcário e produtos similares, na área de buffer de 12 nascentes.

Considerando especificamente o buffer ao longo dos cursos d'água (Figura 6), o uso do solo nessa área demonstra um avançado grau de destruição da vegetação nativa, pois mais de $50 \%$ dessa área está sendo utilizada diretamente por atividades antrópicas que, em termos de legislação específica, caracteriza-se como totalmente irregular.

Como é possível observar na Tabela 2, 48,35\% das áreas de buffer ao longo dos rios da bacia do Barigui estão ocupadas por infraestruturas urbanas.

O maior percentual de área com vegetação nativa remanescente está representado pela Floresta Ombrófila Mista em estágio de sucessão inicial, compreendendo 22,09\%, refletindo que não há qualquer ação efetiva de fiscalização que considere a recuperação dessas áreas e reverta o atual estado de degradação das Áreas de Preservação Permanente ao longo do rio Barigui e de seus afluentes.

Ainda, a área ripária da Bacia ocupada por atividades de extrativismo mineral perfaz $0,49 \%$ daquela área. Muito embora em termos numéricos essa área seja pouco expressiva, em termos de degradação essa atividade é responsável por alterações ambientais significativas pois, além de promover a eliminação imediata da vegetação, promove a destruição dos solos pela abertura da cava, elimina a dinâmica hídrica pelo revolvimento do leito ou pela deposição de partículas sólidas vindas do processo de pesquisa, beneficiamento e da infraestrutura. $\mathrm{O}$ extrativismo de areia e argila, também identificado por Yamamoto (2011), é uma atividade praticada há décadas na porção sul da Bacia. Essa atividade deu origem a uma sucessão de zonas lênticas artificiais (cavas), ou lagoas artificiais, ao longo do rio Barigui e seus afluentes, muitas das quais isoladas do Rio. 


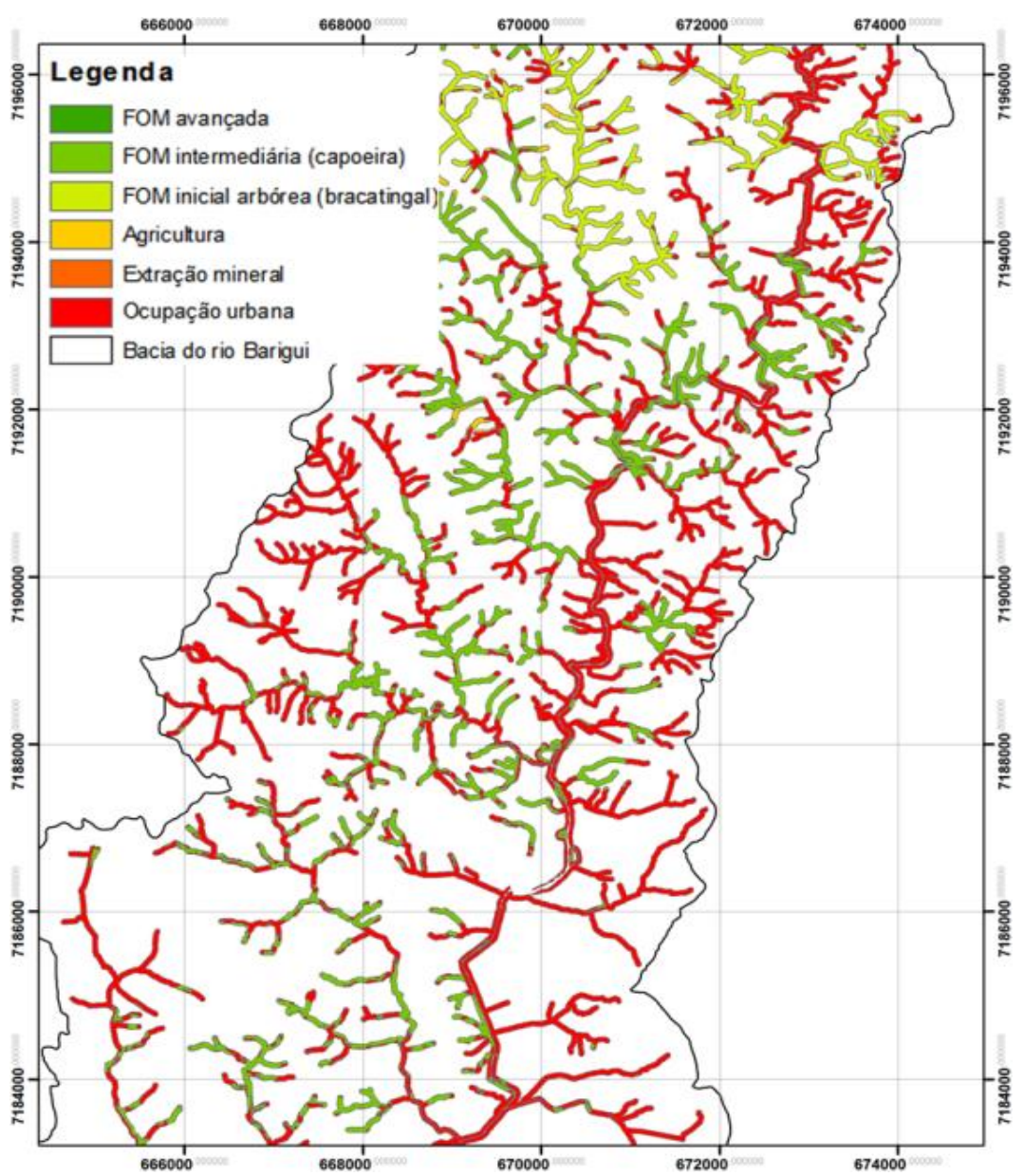

Figura 6: DETALHE DO USO DO SOLO DO BUFFER AO LONGO DAS DRENAGENS NA REGIÃO CENTRAL DA BACIA DO BARIGUI. Fonte: Autor (2010).

A extração mineral de calcário é também uma atividade socioeconômica realizada de forma intensiva e economicamente significativa em toda a porção norte da bacia do Barigui. Ressalta-se que tal atividade está estabelecida no entorno das nascentes do Rio, bem como ao longo de todo o seu trajeto, no município de Almirante Tamandaré.

Os remanescentes da vegetação nativa que podem ser considerados significativos nessa área encontram-se em estágio avançado de sucessão e perfazem apenas $4,65 \%$ da área de preservação permanente ao longo, especialmente, do rio Barigui, na porção sul da bacia.

Da mesma forma, as áreas inundáveis da bacia na área estudada encontramse em grau muito avançado de degradação, com 69,57\% da sua extensão ocupada por urbanizações (Tabela 3). Tais áreas não mais exercem sua função original, a de espraiar o excesso de água das chuvas, tendo sido eliminadas pelas obras de engenharia executadas preponderantemente por programas governamentais, quer 
seja obras de retificação, canalização de percursos, soterramento de nascentes e preenchimento e aterramento de fundos de vale, em benefício da ocupação do espaço pelo assentamento de uma população crescente.

Tabela 2: Ocupação das áreas de buffer ao longo das drenagens da bacia do Barigui.

\begin{tabular}{|l|l|l|l|l|l|l|}
\hline & Urbana & $\begin{array}{l}\text { Agricultur } \\
\text { a }\end{array}$ & $\begin{array}{l}\text { Extração } \\
\text { Mineral }\end{array}$ & $\begin{array}{l}\text { FOM } \\
\text { Avançada }\end{array}$ & $\begin{array}{l}\text { FOM } \\
\text { Intermedi } \\
\text { ária }\end{array}$ & $\begin{array}{l}\text { FOM } \\
\text { Inicial }\end{array}$ \\
\hline $\begin{array}{l}\text { Área Total } \\
\text { (ha) }\end{array}$ & 2278,84 & 143,28 & 23,03 & 219,05 & 1006,95 & 1041,86 \\
\hline $\begin{array}{l}\text { Tamanho } \\
\text { Médio }\end{array}$ & 9,87 & 1,38 & 0,31 & 16,85 & 2,35 & 13,19 \\
\hline $\begin{array}{l}N^{0} \text { de } \\
\text { Polígonos }\end{array}$ & 231 & 104 & 75 & 13 & 428 & 79 \\
\hline$\%$ & 48,35 & 3,04 & 0,49 & 4,65 & 21,37 & 22,11 \\
\hline
\end{tabular}

Tabela 3: Ocupação das áreas inundáveis da bacia do Barigui.

\begin{tabular}{|l|l|l|l|l|l|l|}
\hline & Urbana & Agricultura & $\begin{array}{l}\text { Extração } \\
\text { Mineral }\end{array}$ & $\begin{array}{l}\text { FOM } \\
\text { Avançada }\end{array}$ & $\begin{array}{l}\text { FOM } \\
\text { Intermediária }\end{array}$ & $\begin{array}{l}\text { FOM } \\
\text { Inicial }\end{array}$ \\
\hline $\begin{array}{l}\text { Área Total } \\
\text { (ha) }\end{array}$ & 1801,71 & 0,54 & 58,12 & 259,8 & 364,04 & 105,39 \\
\hline $\begin{array}{l}\text { Tamanho } \\
\text { Médio }\end{array}$ & 23,71 & 0,14 & 0,58 & 17,32 & 2,05 & 2,24 \\
\hline $\begin{array}{l}N^{0} \text { de } \\
\text { Polígonos }\end{array}$ & 76 & 4 & 101 & 15 & 178 & 47 \\
\hline$\%$ & 69,57 & 0,02 & $2,24 \%$ & 10,03 & 14,06 & 4,07 \\
\hline
\end{tabular}

A presença do extrativismo mineral também é evidenciada nessas áreas inundáveis com os mesmos impactos já anteriormente citados. A vegetação lacustre nativa destes espaços foi totalmente eliminada, e como o substrato foi totalmente drenado a vegetação hoje lá encontrada tem características florestais em estágio inicial e intermediário de sucessão, ocupando $18,13 \%$ da área analisada. 
No sul da bacia é onde se encontram os remanescentes de vegetação com maior significado ecológico, ou seja, vegetação florestal em estágio avançado de sucessão.

\section{CONSIDERAÇÕES FINAIS}

O rio Barigui apresenta hoje uma extensão de $66,71 \mathrm{~km}$, considerando que o seu percurso foi retificado na porção central e sul da bacia, com o propósito de conter as cheias que atingiam a população ocupante de suas margens, na planície de inundação.

As áreas de preservação permanente ao longo do rio Barigui, de seus afluentes e das nascentes compreendem uma área total de 7.584,69 hectares, sendo que mais de $62 \%$ dela está ocupada por urbanização.

A ocupação e urbanização em áreas de APP demonstra que o planejamento urbano não contemplou as exigências estabelecidas na legislação ambiental federal - no Código Florestal -, ou, se consideradas, o planejamento não foi implementado.

A área de preservação permanente ocupada pela extração mineral de calcário na porção norte da Bacia e areia e argila na porção sul, é pouco expressiva quantitativamente pois compreende apenas 1,09\%, porém o seu efeito sobre os ecossistemas inundáveis e nos cursos hídricos é altamente impactante, considerando que tal atividade é realizada há décadas.

A agricultura ocupa $2,38 \%$ das áreas de preservação, exercendo maior pressão sobre as áreas de nascentes ocupando 1,88\% do buffer dessas.

A vegetação em estágio avançado de sucessão, pela lógica, deveria ocupar a maior parte das APP, contudo, perfaz apenas 6,10\% da APP. A vegetação restante, nos estágios de sucessão inicial e intermediária, compreende 35,18\%.

Faz-se urgente o estabelecimento de ações que contemplem a reversão do panorama de degradação hoje evidenciado nas APP da bacia do rio Barigui, retirando todas as atividades legalmente conflitivas.

Considerando que a água é o recurso natural que sustenta a vida, o descaso das autoridades públicas para com os instrumentos legais que promovem a conservação dos cursos d'água demonstra a falta de percepção, de comprometimento e de responsabilidade, de fato, para com as questões ambientais. 
Qualquer curso d'água deve ser considerado e mantido em sua forma natural, mesmo em áreas urbanas, pois é através das drenagens que a águas das chuvas são escoadas, estando associado à manutenção de áreas com vegetação nativa, ou seja, sem impermeabilização, para que essa água possa ser gradativamente absorvida, seguindo seu ciclo natural, eliminando as enxurradas.

\section{AGRADECIMENTOS}

Daniel Dupré, Instituto ECOS, COMEC, SUDERHSA.

\section{Referências}

AUER, A.M. Avaliação dos processos de ocupação antrópica da bacia do Rio Barigui e suas implicações ecológicas. Tese (doutorado) - Universidade Federal do Paraná, Setor de Ciências Agrárias, Programa de Pós-Graduação em Engenharia Florestal. Curitiba, 2010.

AUER, A. M. AÇÃO CIVIL PÚBLICA No. 2001.70.00.000582 da Vara Ambiental Federal de Curitiba. Laudo Pericial Florestal. Curitiba, 2009.

AUER, A.M. Avaliação das unidades de conservação do estado do Paraná e da viabilidade de um sistema de unidades de conservação. Dissertação (mestrado) - Universidade Federal do Paraná, Setor de Ciências Agrárias, Programa de PósGraduação em Engenharia Florestal. Curitiba, 1995.

BRASIL, PRESIDÊNCIA DA REPÚBLICA CASA CIVIL SUB-CHEFIA PARA ASSUNTOS JURÍDICOS. LEI № 12.651, DE 25 DE MAIO DE 2012. Brasília, 2012.

BOLLMANN, H.A. and MARQUES, D.M.L. da Motta. Influência da densidade populacional nas relações entre matéria orgânica carbonácea, nitrogênio e fósforo em rios urbanos situados em áreas com baixa cobertura sanitária. Revista Eng. Sanit. Ambient., Dez 2006, vol.11, no.4, p.343-352.

CONSELHO NACIONAL DO MEIO AMBIENTE - CONAMA. Resolução 2/94 (estabelece as características da vegetação primária e secundária da Mata Atlântica no Estado do Paraná).

COORDENAÇÃO DA REGIÃO METROPOLITANA DE CURITIBA - COMEC. Plano de zoneamento do uso e ocupação do solo da região do karst da Região Metropolitana de Curitiba. Paraná. 2002.

FILL, H. D.; SANTOS, I.; FERNANDES, C. V. S.; TOCZECK, A.; OLIVEIRA, M. F. DE. Balanço hídrico da bacia do rio Barigui, PR. Revista RA'E GA, Curitiba, n. 9, p. 59-67, 2005. Editora UFPR.. 
IBGE - Instituto Brasileiro de Geografia e Estatística. Manual técnico da vegetação brasileira. Séries Manuais técnicos em geociências, n. 1, Rio de Janeiro, 1992. 92p.

IBGE - Instituto Brasileiro de Geografia e Estatística. Mapa de vegetação do Brasil. Escala: 1:5 000 000, UF: AC. IBGE: Rio de Janeiro, 1988.

BOLOS, O.; CERVI, A. C.; HATSCHBACH, G. Estúdios sobre la vegetacion del estado del Paraná (Brasil meridional). Collectanea Botânica, v.20, p.79-182. 1991. IAP - Instituto Ambiental do Paraná. Monitoramento da qualidade dos rios da Bacia do Alto Iguaçu, na região metropolitana de Curitiba, no período de 2005 a 2009. IAP, 2009.

IAPAR - Instituto Agronômico do Estado do Paraná. Cartas Climáticas do Paraná - Disponível em

<http://www.iapar.br/modules/conteudo/conteudo.php?conteudo=863 >. Acesso em 14 de setembro de 2013.

COORDENAÇÃO DA REGIÃO METROPOLITANA DE CURITIBA - COMEC. Plano de zoneamento do uso e ocupação do solo da região do karst da Região Metropolitana de Curitiba. Paraná. 2002.

MAACK, R. Geografia física do estado do Paraná, 2 ed., J. Olympio, 168 p., Rio de Janeiro, 1981.

MAACK, Reinhard. A modificação da paisagem natural pela colonização e suas consequências no norte do Paraná, Boletim Paranaense de Geografia, Curitiba, v. 1, n. 2/3, p. 29-45, 1961.

MINEROPAR. Lineamentos traçados sobre as interpretações de imagens RADAM digitalizadas 400 dpi georreferenciadas UTM SAD $69 \mathrm{em}$ escala de monitor 1:100.000. Curitiba, 2002.

REIS, B. J.; BATISTA, G. T.; TARGA, M. S. e CATELANI, C. S. Influência das cavas de extração de areia no balanço hídrico do vale do Paraíba do Sul. Revista Escola de Minas [online]. 2006, vol.59, n.4, pp. 391-396.

RODERJAN, C. V.; GALVÃO, F.; KUNIYOSHI, Y. S.; HATSCHBACK, G. As unidades fitogeográficas do Estado do Paraná. Ciência \& Ambiente, Santa Maria, v.24, p.75-92, jan./jun. 2002.

NETO, A. S. R. Análise da conjuntura agropecuária, safra 2010/2011. ESTADO DO PARANÁ, SECRETARIA DA AGRICULTURA E DO ABASTECIMENTO DEPARTAMENTO DE ECONOMIA RURAL. 2010.

SUDERHSA (SUPERINTENDÊNCIA DE DESENVOLVIMENTO DE RECURSOS HÍDRICOS E SANEAMENTO AMBIENTAL. Plano da bacia do Alto Iguaçu e afluentes do Alto Ribeira. Relatório de Diagnóstico. Curitiba. 2007. 
SANEPAR (COMPANHIA DE SANEAMENTO DO PARANA). Relatório de atividades. Curitiba, 2002.

VELOSO, H. P. \& GÓES-FILHO, L. Fitogeografia Brasileira. Classificação fisionômico-ecológica da vegetação neotropical. Boletim Técnico Projeto RADAMBRASIL. Série vegetação. 1982.

VELOSO, R. B.; RANGEL FILHO, A. L. R.; LIMA, J. C. A. Classificação da vegetação brasileira, adaptada a um sistema universal. Rio de Janeiro: IBGE. 1991.

SANEPAR (COMPANHIA DE SANEAMENTO DO PARANA). Relatório de atividades, Curitiba, 2002.

SUDERHSA (SUPERINTENDÊNCIA DE DESENVOLVIMENTO DE RECURSOS HÍDRICOS E SANEAMENTO AMBIENTAL, Plano da bacia do Alto Iguaçu e afluentes do Alto Ribeira. Relatório de Diagnóstico. Curitiba. 2007.

YAMAMOTO, C. R. G., Wetlands na região metropolitana de Curitiba - PR: gestão e desafios. Revista Caminhos de Geografia, Uberlândia, v.13, n.42, jun/2012. p. 138-156.

(Recebido em 28.08.2014; Aceito em: 25.09.2015) 